\title{
GRAMMAR IN SPECIALIZED TRANSLATION CLASSES
}

\author{
Daniela DOBOȘ \\ Alexandru Ioan Cuza University of Iași, Romania
}

\begin{abstract}
The main focus of specialized translation classes is usually terminology, but in many cases that is not enough, particularly in situations where the students' L2 level is below the required standard, so that much remedial grammar teaching is needed. This paper argues that in such situations, if not as a rule, both explicit and implicit grammar teaching should be a part of translation classes, before discussing the author's long-term practice of conceptualizing grammar. The teaching of tense, aspect and complex noun phrases is then introduced with examples.
\end{abstract}

Keywords: grammar teaching; grammar conceptualization; noun phrases; verb phrases; specialized translation

\section{Introduction}

After 1989 the English Department of the Faculty of Letters at the "Alexandru Ioan Cuza" University of Iaşi, Romania's oldest university, set up an Applied Linguistics course of studies mainly for the training of translators and interpreters. At that time the applicants' level of English met the required standards as a result of the compulsory entrance examination, so that upon graduation quite a few students went on to pass the entrance tests for E.U. translators in Brussels. The year 2000 saw the abolition of the entrance examination, a situation which quickly resulted in constantly lower academic achievement and large numbers of failing grades. The Bologna structural reform only made things worse since upon adaptation of the former four-year curriculum the cuts affected the practical rather than the theoretical courses, thus depriving the students of much-needed English language practice. 
This study was prompted by the constant low academic achievement of the students enrolled in the Applied Linguistics module at our university, whose level of English is clearly below the required academic standards, while the fact that they study two foreign languages during the three-year course of studies is an aggravating factor. The current curriculum does not provide enough grammar classes, which should be taught by tutors with an in-depth knowledge of English grammar: a single $2 \mathrm{hrs} /$ week practical grammar course in the first year of studies, while the number of specialized translation courses is much larger: 2 $\mathrm{hrs} /$ week in the first year, $4 \mathrm{hrs} /$ week in the second and $2 \mathrm{hrs} /$ week in the third. Translation, on the other hand, whether literary or specialized, requires appropriate command of both the source and the target languages. Furthermore, translators need systematically to compare the structures of the languages with which they are working.

Consequently, the place of foreign-language grammar at university level in general, and in the training of applied linguists/ translators in particular, appears to be a legitimate question. This study argues that grammar should be an important part of the syllabus of the specialized translation courses as well, since as linguist M.A.K. Halliday rightly posits it, it is not just vocabulary that characterizes specialized discourse, but the lexicogrammar ('sentence grammar'): "We start from the lexical end-the vocabulary-because, within the lexicogrammar, it is the vocabulary, or lexicon, that is nearer the surface of consciousness. It is easier to pay attention to the vocabulary than to the grammar." (Halliday 1993: 139) Debates around the notion of grammar have a long history and in recent times they have been particularly animated, and even violent, hence the phrase "the grammar wars" (Locke 2010).

\section{Brief Survey of Debates on Grammar Teaching in the Foreign Language Class}

In the context of foreign language teaching, the main issue has been whether grammar ought to be taught deductively of inductively. Theorists of the deductive approach argue that learners should have an explicit knowledge of grammar in order to consciously acquire the foreign language grammar rules and be able to compare these with the rules of their native languages. Authors arguing the inductive approach hold that the foreign language grammar rules may be 'induced' in an appropriately organized language input. It is worth pointing out that explicit grammar teaching has a very long history, beginning with the ancients. The inductive approach was most successful in the framework of audiolingualism, which drew its theoretical foundations from behaviourist psychology, holding that a foreign language was learnt through imitation and 
habit formation, while banning explicit grammar teaching; as such inductivism has regarded grammar as a natural phenomenon.

Chomsky's work has revolutionized the concept of 'grammar', seen as a property of the mind rather than a property of language. Chomsky's Language Acquisition Device (LAD) hypothesis was at the same time a rebuttal of the inductive approach with its mechanistic view of language learning, while also establishing the term 'acquisition' in place of 'learning' for the process engaged in by the child assimilating the mother tongue. Controversy arose as to whether the innate heuristics making this process possible functions indefinitely or whether there comes a cut-off point, established at puberty, so that additional languages have to be learnt rather than acquired, with the help of adult cognitive abilities.

In the 1980s the debate was further complicated by Krashen and Terrell's Natural Approach (1983). Krashen argued that foreign language learners may both 'acquire' and 'learn'; on this view, 'acquiring' is inducing the language through exposure to it, while 'learning' is gaining formal knowledge of it. Thus acquisition, which cannot be taught, implies the building up of a grammar through creative construction, and learning, which can be assisted through teaching, implies the conscious amassing of knowledge about the language. Krashen (1982) further argued that acquisition and learning are separate devices, in the sense that what has been learnt cannot pass into the acquired system, which is responsible for all spontaneous language use although, in certain specified circumstances, the learnt system can intervene to monitor accuracy; in other words, the learning of grammar does not assist in spontaneous production but can to some extent correct it (1982: 15). Currently however many theorists, including Chomsky himself, suspect that while all human beings can learn implicitly, a specific LAD may not be available to L2 learners beyond the age of 7 (Towell \& Hawkins 1994: 14-15).

In the 1990s a number of theorists (e.g. Rutherford 1987; Fotos \& Ellis 1991) have argued "consciousness raising", defined as "the drawing of the learner's attention to features of the target language" (Rutherford 1987: 189), which has three distinct advantages:" learning will be faster, the quantity produced will be greater and the contexts in which the rule can apply will be extended" (Rutherford 1987:26).

Recent research findings have suggested that attention to form is a necessary condition for language learning (Kachru 2006: 249; Thornbury 1999: 116), while meaning-focused communicative tasks, with no method of creating awareness of the grammatical system, are inadequate and do not lead to accuracy in language use (Skehan 1998 quoted in Kachru 2006). Cowan (2008: 30-31) quotes an abundance of research that shows that "classroom instruction in grammar actually results in substantial gains in L2 proficiency", while explicit teaching produces better and longer-lasting learning than implicit teaching 
(Norris and Ortega 2000 quoted in Cowan 2008: 57). On the other hand, the question whether control of a foreign language grammar can be built up consciously and by what means cannot yet receive a definitive answer. To date, the neural basis for language itself is not fully understood.

\section{Conceptualizing Grammar}

I teach what might be called "remedial English grammar" to large multilevel classes of first-year students majoring in Translation Studies ( $1^{\text {st }}$ semester), besides specialized translation to second-year students. In the teaching context detailed in the introduction, it has long become obvious to me that grammar must be a part of the specialized translation courses as well because the first-year grammar instruction is not enough. Translation is impossible in the absence of thorough knowledge of both the SL and the TL; thus grammar is a must for every competent translator. In the first semester my grammar course begins with the English tenses. I usually ask the students if they can account for the fact that the first unit of the language study section of most if not all English language textbooks deals with the tenses. No one knows the answer to this question, which gives me the opportunity to explain the role of the verb in the sentence and that all the other elements of the sentence depend on it. The verbal system is the most complex part of the grammar of English.

\subsection{Tense and Aspect}

The first distinction that applies with the English tenses is that between grammatical tense and conventional time. In Chalker \& Weiner's Oxford Dictionary of English Grammar (1998: 395), tense refers to "the form taken by a verb to indicate the time at which the action or state is viewed as occurring", but immediately below this definition comes T. F. Mitchell's (1975) remark that "there is no coherent relation between tense and time", as past and present tenses, for example, can be used to refer to future time.

Linguists argue that English has a binary (two-way) tense system, with the present (non-past) tense defined as unmarked and "timeless in the sense that it can embrace any time that does not exclude the speaker's time [...] and any time that the speaker does not want to distance himself from", and the past tense defined as "marked for separation from the speaker's 'now', or to indicate the hypothetical nature of the statement, or to convey social distancing" (Chalker and Weiner 1998: 395). Chiţoran (1976: 17) writes that "the English tense system is difficult for the Romanian learner because, although both languages can easily be described as having only two major tenses (Present and Past), the number of tense forms is widely different in the two languages". The Romanian tenses are Prezent, Imperfect, Perfect Simplu (only regionally used), Perfect 
Compus, Mai-mult-ca-Perfect, Viitor and Viitor Anterior (rare). English textbooks describe either 8 or 12 tenses, and although this use tense is not linguistically correct, these sheer numbers are likely to baffle learners from the start.

Moreover, for Romanian learners of English, the grammatical category of aspect is bound to present major difficulties, mainly because in Romanian aspect is lexicalized by means of adverbials, verbs - a incepe să, a se apuca de, a termina de a.s.o., and morphemes, e.g. a amuţi/adormi etc, subordinated to the category of tense..Besides L1/L2 differences, additional learning problems are generated by the manner in which the grammar of the verb is presented in most ELT materials, implying long lists of tenses, verb forms and their uses, often with insufficient and/or confusing or even contradictory explanations, e.g. "When referring to the present or future, these expressions (I wish/If only) are followed by a past tense" (O'Connell, Focus on First Certificate, 1996: 210). In contrast to such explanations, several areas of grammar - tenses included - are amenable to conceptualization and to teaching and learning in terms of meaning, which implies a shift from a purely structural, to a more functional description.

Thus, for teaching/learning purposes, the complexity of English verb tenses can be subsumed to three elements of meaning:

- factuality (fact vs. non-fact: what is real or considered possible vs. what is only imagined, hypothesized or wished for);

- time (with reference to the time of the event);

- aspect $\rightarrow$ grammatical (how the speaker sees the verb action)

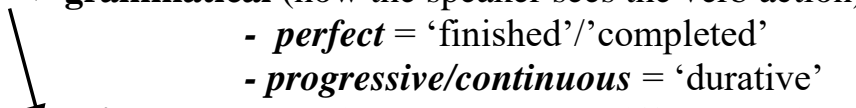

lexical (verb meanings: verbs carry different periods of duration).

For the same purposes, the meanings of the main terms used to refer to the tenses can be summarized as follows:

\begin{tabular}{|c|c|c|}
\hline Present & means & {$[+$ fact $][+$ close to the speaker's situation $]$} \\
\hline Past & means & $\begin{array}{l}\text { either }[+ \text { fact }] \rightarrow[+ \text { remote in time }] \\
\text { or }[- \text { fact }] \rightarrow[+ \text { remote in time/ reality/ social distance }]\end{array}$ \\
\hline Perfect & means & [+before] [+ connected to a point in time - present or past] \\
\hline Simple & means & [+complete] \\
\hline $\begin{array}{l}\text { Continuous/ } \\
\text { Progressive }\end{array}$ & means & [+duration] \\
\hline
\end{tabular}

I have found that such conceptualization works better than time lines drawn on the black/white board which, depending on the graphic abilities of the teacher, can take various composite forms involving straight and wavy lines, triangles and dots, yielding further graphic abstraction. Conceptualization seems 
to provide students with a feeling of security and confidence. Later I found support for this idea in the literature, for example Celce-Murcia and LarsenFreeman (1999: 4): "teachers (and consequently, their students) are helped by understanding English when generalizations can be made at the highest possible level of language [...] Giving students reasons for why things are the way they are can aid students in learning English grammar."

Translating the tenses between English and Romanian should not present much difficulty once the rationale for their uses has been understood. Romanian translators should pay particular attention to the adjoining adverbials, which can be confusing, since in Romanian the Prezent and Imperfect occur freely with open-time adverbials. Linguists have argued that tense usage in specialized texts, such as research articles, involves "strategic choices that provide authors with the capability of manipulating temporal references for their own rhetorical purposes" (Malcolm 1987: 32), which translators of such texts should heed. Biber (1988) and Biber and Conrad (2009) provide detailed accounts of the relevant linguistic features across registers and genres, while Swales (1990) provides a survey of the relevant linguistic features of research articles. Such resources should be used not only by teachers of English, but also by translators from English.

\subsection{Complex Noun Phrases}

There is general agreement on the fact that the complexity of noun phrases is not only structural, but also lexical and referential (Nash 1980: 66), unlike verb phrases, which display less referential complexity. Noun phrases, also called nominal groups, are powerful resources for creating meaning as a result of the fact that they can be expanded to a more or less infinite extent. While the verb phrase, or verbal group, expands grammatically on the temporal dimension, with tense, aspect and modality, the noun phrase expands lexically by means of modification. Modern English exhibits a general preference for recursively structured noun phrases which originated, as Halliday has shown, in the $16^{\text {th }}$ century with the shaping of scientific English, "by the birth of grammatical metaphor, from the union of nominalization with the recursive modification of the nominal group" (Halliday 1993: 16-17). Halliday further notes that this powerful kind of grammar has taken over and become norm:

But whereas this nominalizing was functional in the language of science, since it contributed both to technical terminology and to reasoned argument, in other discourses it is largely a ritual feature, engendering only prestige and bureaucratic power. It becomes a language of hierarchy, privileging the expert and limiting access to specialized domains of cultural experience. (Halliday 1993: 17) 
There are indeed countless instances of unwarranted use of nominalization and abstraction to mislead and mystify (McKenna \& Graham 2000), including the social sciences, which now often display what has been termed an "official style" employing expressions such as "self-initiated instrumentality" or "innermotivated disinclination for on-going participation in human existence". At the beginning of the translation process, as translators establish the genre of the text, they are held to be aware of instances of technocratic writing, which Newmark subsumes to jargon:

...platitudinous or meretricious thought 'dressed' either in the colourless language of bureaucracy (technocracy, chancery language, Marxism, officialese) or in the literary/national tradition of a 'folk', e.g., German philosophical obscurity, or late nineteenth century sensuality and religiosity." Newmark further remarks that "how far the translator can go in reducing the jargon depends on two factors: (a) the degree of authoritativeness of the SL statement (i.e., the less authoritative, the more linguistic changes can be made); (b) the norms of the SL and TL. (Newmark 1988: 210)

Besides problems of deficient style, however, translators, especially those whose L1 is very different from English, must also be aware of the structure and potential of the English noun phrase, mainly because its structure is an index of register. Halliday argues that pre-modifiers represent various degrees of permanence, whereby the more permanent the attribute, the closer it is placed to the Head. If there is more than one pre-modifier, here is a tendency to move from successively less identifying or specifying attributes to more permanent ones, and further notes that although the two noun groups a weatherboard shack by the roadside and a roadside shack made out of weatherboard do not differ in their logical or experiential structures, the corresponding difference in information structure (textual meaning) indicates that they are not synonymous (Halliday 1985: 171).

In specialized writing, Halliday (1993) as well as other authors, such as Dubois (1982), have shown that nominal groups serve more than one function: objectification, or turning concrete processes into abstractions, e.g. reduction vs. to reduce/ cut down on, which allows for their further analysis and study; the establishment of clear logical relations among entities, attributes and states, which results in the patterns that are typical of scientific argumentation and, most important, the foregrounding and/or backgrounding of the information in ways that allow an argument to be effectively developed. Thus translators of specialized texts must understand the movement of modifiers from post-nominal to pre-nominal position, and from rheme to theme, as an index of the author's assessment of the recoverability of information, a process which can be schematized as: the NP is $X \rightarrow$ the $X$ NP is $Y \rightarrow$ the $X Y$ NP is $Z$..., e.g. 
Studies of the oxidative NADP in enzymes in Drosophilla melanogaster have concentrated on the relationship of gene dosage to the in vitro tissue enzyme level and on allelozyme variation $\rightarrow$ Drosophilla melanogaster oxidative NADP-enzyme studies have concentrated on the gene dosage to the in vitro tissue enzyme level relationship (Dubois 1982: 51). In Romanian, the normal slot for modifiers is post-nominal, so that modifier movement is not possible beyond one. Consequently, in students' translation the order of constituents is likely to present problems.

In my specialized translation classes I use samples from various genres and fields so that students become acquainted with as many examples of complex noun phrases with varied structures as possible. First students are required to bracket the noun phrases and analyze their structure, by identifying the head and then the pre- and post-modification structures, identification of noun compounds and order of adjectives in pre-modifier position, activities which support "consciousness raising" and equip them for the course in English syntax which they take in the second year. Further linguistic features of texts are discussed, such as the use of tenses and modal auxiliaries and other relevant syntactic structures. Students are also expected to identify the genre each sample typifies, such as various types of reports, following the course in Languages for Special Purposes which they take in the first year. Translation comes only after linguistic analysis.

Three examples of texts I use in class:

"[The Irish Republic's capital, and its largest and most vibrant city, Dublin], makes a fine introduction to the country. It has [a reputation out of all proportion to its small size]. Of roughly one and a half million people in an area of only 20 sq miles, the city has spawned [more than its fair share of authors, poets, playwrights, satirists, musicians and politicians]. Small thou it is, Dublin has [plenty of exciting things to do and see]. [Many of the greatest attractions] are packed together in the city centre, so even if you're short of time, you can still dip into[ the honey pot]". [from a holiday guide-book]

"Seldom can ignorance have played such a vital part in saving [a great work of art]. [The magnificent, larger-than-life-size gilded bronze equestrian statue of Marcus Aurelius] would almost unquestionably have been melted down during [the wholesale destruction of pagan art] in the centuries after the triumph of Christianity had it not been mistaken for [an image of Constantine, [the ruler who made the new faith the official religion of the empire and was subsequently sanctified]]". [from a newspaper report]

"Weighed down by [the high cost of restructuring and slow vehicle sales], Ford reported Friday [a \$1.2 billion loss for the first three months of the year], its steepest since 2001. The announcement came one day after General Motors, Ford's main rival in the United 
States, said it lost $\$ 323$ million in the first quarter. Both automakers have announced [sweeping plans to eliminate a combined 60,000 jobs and shut down more than two dozen factories] as [their share of the North American auto market] continues to shrink". [from a business report]

Among the proposed texts there will also be samples in which the students have to trace the pattern which is typical of scientific English, the $\mathbf{N P}$ is $\mathbf{X} \rightarrow$ the $\mathbf{X}$ $\mathbf{N P}$ is $\mathbf{Y} \rightarrow$ the $\mathbf{X Y} \mathbf{N P}$ is $\mathbf{Z}$.., a skill which is then reinforced by means of exercises which require them to manipulate such structures.

On concentrating on the functions of pre- and post-modification, I point out that information before the head noun creates a more descriptive style, such as occurs in advertisements, journalism and various descriptions, while post-modifying structures tend to produce a more defining style. As Carter et al (2000: 128) note, "both scientific and academic writing as well as informal conversation styles can be characterized by more complex post-modifying structures". Carter at al's Exploring Grammar in Context, which its authors describe as one that distinguishes between "grammar as structure" and "grammar as choice" (2000: vii), is one of very few grammars which take an inductive approach, giving learners the opportunity to work out the rules for themselves, while using authentic samples of language.

\section{Conclusion}

This paper argues that grammar is the most distinctive aspect of language, also its "basic thought-carrying element", as translation theorist Peter Newmark writes (1988: 73); consequently both explicit and implicit grammar teaching should be a part of specialized translation classes. This is mainly because in many cases, the number of practical grammar classes at academic level is low and there is not enough time to allow students to reach the language level required for translation work. Often at academic level students will want explanations for grammatical phenomena, and only grammar can provide a systematic framework for language teaching and learning. This paper has also argued that at academic level conceptualization of grammar should be used. Students should be given ample opportunities to focus on relationships between form and function, which will enable them to perceive patterns, gives them confidence, and paves the way to consciousness raising and language awareness.

\section{Works Cited}

Biber, D., Variation across Speech and Writing, Cambridge, Cambridge University Press, 1988.

Biber, D., and Susan Conrad, Register, Genre, and Style, Cambridge, Cambridge University Press, 2009. 
Carter, R., Rebecca Hughes, and Michael McCarthy, Exploring Grammar in Context, Cambridge, Cambridge University Press, 2000.

Celce-Murcia, M., and Diane Larsen-Freeman, The Grammar Book. An ESL/EFL Teacher's Course, Boston, Heinle \& Heinle, 1999.

Chalker, S., and Edmund Weiner, The Oxford Dictionary of English Grammar, Oxford \& NewYork, Oxford University Press, 1998.

Chiţoran, D., "Report on the Romanian-English Contrastive Analysis Project" in 2nd International Conference of English Contrastive Projects (Bucharest, 20-23 November, 1975). Ed. Dumitru Chiţoran, Bucharest, Bucharest University Press, 1976.

Cowan, R., The Teacher's Grammar of English. A Course Book and Reference Guide, Cambridge, Cambridge University Press, 2008.

Dubois, B.-L., "The construction of noun phrases in biomedical journal articles" in Pragmatics and LSP. Proceedings of the $3^{\text {rd }}$ Symposium on LSP, Eds. J. Hoedt, L. Lundquist, H. Picht and J. Qvistgaard, Copenhagen, Copenhagen School of Economics, 1982.

Fotos, S. and Rod Ellis, "Comunicating about Grammar: A Task-Based Approach" in Tesol Quarterly, Winter (1991).

Halliday, M.A.K., An Introduction to Functional Grammar, London, Edward Arnold, 1985.

Halliday, M.A.K., and J.R. Martin, Writing Science: Literacy and Discursive Power, London \& Washington D.C., The Falmer Press, 1993.

Kachru, Y., "Pedagogical Grammars: Second Language" in Encyclopedia of Language and Linguistics vol. 10, Eds. Keith Brown. et al., Oxford, Elsevier, 2006.

Krashen, S. D., Principles and Practice in Second Language Acquisition, Oxford, Pergamon Press, 1982.

Krashen, S. D., and Tracy D. Terrell, The Natural Approach. Language Acquisition in the Classroom, Oxford, Pergamon Press, 1983.

Locke, T., Beyond the Grammar Wars: A Resource for Teachers and Students. On Developing Language Knowledge in the English/ Literacy Classroom, London, Routledge, 2010.

Malcolm, L. "What rules govern tense usage in scientific articles?" in English for Specific Purposes Issue 6, 1987.

McKenna, B., and Philip Graham, "Technocratic discourse: A Primer" in Journal of Technical Writing and Communication, Issue 30, 3/ 2000.

Nash, W. Designs in Prose: A Study of Compositional Problems and Methods, London, Longman, 1980.

Newmark, P., A Textbook of Translation, London, Pearson Longman, 1988.

O’Connell, S., Focus on First Certificate, Harlow, Longman, 1996.

Norris, J. M, and L. Ortega, "Effectiveness of L2 instruction: A research synthesis and quantitative meta-analysis" in Language Learning, Issue 50, 2000.

Rutherford, W. E., and Mike Sharwood-Smith, "Consciousness-raising and universal grammar" in Applied Linguistics, Issue 6, 3/1985.

Rutherford, W., Second Language Grammar: Learning and Teaching, London, Longman, 1987. 
Skehan, P., A Cognitive Approach to Language Learning, Oxford, Oxford University Press, 1998.

Swales, J., Genre Analysis. English in Academic and Research Settings, Cambridge, Cambridge University Press, 1990.

Thornbury, S., How to Teach Grammar, Edinburgh, Pearson Longman, 1999.

Towell, R., and Roger Hawkins, Approaches to Second Language Acquisition, Clevedon, Multilingual Matters, 1994.

\section{BIONOTE}

DAniela Doboş is Associate Professor in the Department of English of the Faculty of Letters, "Alexandru Ioan Cuza" University of Iaşi, Romania. Her research interests are English and Romanian grammar and linguistics, specialized translation and cultural studies. She has published extensively in various journals and in various collections of essays. Among her latest articles are "Vulgar Slang in English and Romanian. A Few Notes on Romanian Hip Hop Lyrics Translated into English" in Argotica No 1(3)/2014 and "The West Going East: Archaic Romania in Western Authors' Travel Writings of the Late Twentieth Century" in Views of the East. Travel and Intercultural Communication in Europe, "Alexandru Ioan Cuza" Publishing House, 2016. She is the author of two books on English linguistics.

Email: dana_dobos@yahoo.com 
